\title{
Rare Helicobacter pylori Infection May Explain Low Stomach Cancer Incidence: Ecological Observations in Bali, Indonesia
}

\author{
Tsutomu Tanaka ${ }^{1,2}$, I Ketut Mulyadi ${ }^{3}$, Moestikaningsih ${ }^{3}$, Tjok Gede Oka ${ }^{4}$, \\ Soeripto $^{5}$, FX Ediati Triningsih ${ }^{5}$, Teguh Triyono ${ }^{6}$, Didik Setyo Heriyanto ${ }^{5}$, Akihiro \\ Hosono $^{7}$, Sadao Suzuki ${ }^{7}$, Shinkan Tokudome ${ }^{1,7,8 *}$
}

\begin{abstract}
The incidence rate of stomach cancer in Bali, Indonesia, is estimated to be strikingly lower than that in Japan. We conducted an on-site ecological study to investigate the association between the stomach cancer incidence and Helicobacter pylori (H. pylori) infection. Recruiting 291 healthy persons (136 men and 155 women) from the general population in Bali, Indonesia, we conducted a urea breath test (UBT) to examine $H$. pylori infection, along with a pepsinogen test to detect chronic atrophic gastritis and urine analysis to estimate sodium and potassium excretion. UBT positivities were 9\% (2-15, $95 \%$ confidence interval) for men and $7 \%$ (1-12) for women, and positive cases for $\mathrm{H}$. pylori IgG antibodies were $1 \%(0-3)$ for men and $3 \%(0-5)$ for women, significantly lower than the respective values in Japan. Positive pepsinogen tests in Bali were 0\% (0-0) for men and 1\% (0-4) for women, also significantly lower than the Japanese figures. Computed values for daily salt excretion were $13.3 \pm 4.1 \mathrm{~g}$ (mean $\pm \mathrm{SD}$ ) for men and 11.1 $\pm 3.1 \mathrm{~g}$ for women, as high as corresponding Japanese consumption values. Moreover, the estimated potassium excretion was $3.2 \pm 0.7 \mathrm{~g}$ for men and $2.8 \pm 0.6 \mathrm{~g}$ for women in Bali, significantly higher than the figures in Japan. There were no associations across genetic polymorphisms of IL-beta, TNF-alpha, and PTPN11 with UBT positivity. The low incidence of stomach cancer in Bali may thus mainly be due to the rare $H$. pylori infection. Namely, the bacterium infection seems to be a critical factor for gastric cancer rather than host or other environmental factors.
\end{abstract}

Keywords: Bali - ecological study - incidence of stomach cancer - prevalence of Helicobacter pylori - urea breath test

Asian Pac J Cancer Prev, 17 (3), 979-984

\section{Introduction}

Helicobacter pylori (H. pylori) is regarded as a carcinogen for stomach cancer along with other contributory factors, such as smoking and intake of salt and salty foods (IARC, 1994; 2003; Graham and Graham, 2002; WCRF/AICR, 2007). It destroys gastric mucous membranes and induces chronic atrophic gastritis which is the precursor lesion for stomach cancer (Parsonnet et al., 1991; Graham and Graham, 2002; Oishi et al., 2006).

Similar to Indonesian ethnic groups, Malay people are well-known to have a low stomach cancer incidence, compared with high-incidence populations like Japanese and Chinese (IARC, 2002; Ministry of Health, Malaysia, 2002; Soeripto et al., 2003; RGPCRJ, 2003). Since it has been suggested that the incidence of stomach cancer is low in Bali, Indonesia from a hospital-based cancer registry
(Soeripto, 2003), we conducted an on-site ecological study of stomach cancer to elucidate the risk/preventive factors of stomach cancer by sampling breath, blood and urine, and by conducting a surveillance of smoking and alcohol drinking habits and consumption of vegetables and fruit, salt and salty foods.

\section{Materials and Methods}

\section{Subjects}

In February 2006, we (IKM, M, and TGO) recruited 291 healthy volunteers (136 men and 155 women) from the general population in Bali, Indonesia.

\section{Questionnaire survey}

At Sanglah Hospital in Bali, the subjects were requested to respond to an interview-based questionnaire on lifestyle

${ }^{I}$ Department of Health and Nutrition Policy, Nagoya City University Graduate School of Medical Sciences, ${ }^{2}$ Department of Obstetrics and Gynecology, Minami Seikyo Hospital, Nagoya, Japan, ${ }^{3}$ Department of Anatomical Pathology, ${ }^{4}$ Department of Clinical Pathology, Faculty of Medicine, Udayana University, Denpasar, Bali, Indonesia, ${ }^{5}$ Department of Anatomic Pathology, ${ }^{6}$ Department of Clinical Pathology, Faculty of Medicine, Gadjah Mada University, Jogjakarta, Indonesia, ${ }^{7}$ Department of Public Health, Nagoya City University Graduate School of Medical Sciences, ${ }^{8}$ Department of Nutritional Epidemiology, National Institute of Health and Nutrition, Tokyo, Japan*For correspondence: tokudome2013@gmail.com 
factors, including smoking, alcohol consumption and dietary habits, recent use of antibiotics, and drinking well water along with ethnicity (Balinese or Javanese) and religion.

\section{Breath sampling}

Using UBiT-IR300 kits (Otsuka Pharmaceutical Co., Tokyo, Japan), breath was sampled at the hospital for 13C-UBT (Graham et al., 1987) with $\geq 2.5 \%$ denoting positive testing.

\section{Blood sampling}

Overnight-fasting venous blood was sampled by hospital technicians to detect serum IgG antibodies for $H$. pylori and $\mathrm{HAV}-\mathrm{Ab}$, and to assess serum concentrations of PG I and PG II. Serum H. pylori IgG antibodies were examined using enzyme immunoassay (EIA) kits (Eiken Chemicals, Tokyo, Japan), and EIA values of $\geq 10 \mathrm{U} /$ $\mathrm{ml}$ were defined as positive. For the subjects showing positive UBT testing, serum CagA IgG antibodies were detected by enzyme-linked immunosorbent assay (ELISA) kits (Genesis Diagnostics Ltd., Cambridgeshire, United Kingdom) and ELISA values of $\geq 6.25 \mathrm{U} / \mathrm{ml}$ were defined as positive (Parsonnet et al., 1997; Ohata et al., 2004). Serum PG I and PG II were measured by chemical luminescence immunoassay (Abbott Japan Co. Ltd., Tokyo, Japan) with cut-off points at PG I $<=70 \mathrm{ng} / \mathrm{ml}$ and PG I/PG II <= 3.0 (Miki et al., 2003). HAV-Ab were analyzed by EIA (Abbott Japan Co. Ltd., Tokyo, Japan) (Fiore, 2004). Using white blood cells, we identified single-nucleotide polymorphisms (SNPs) of interleukin1-beta C-31T (IL-1 $\beta$ C-31T), tumor necrosis factor-alpha T-1031C (TNF- $\alpha$ T-1031C), and PTPN11 G/A at intron 3 by two pairs of polymerase chain reaction (PCR-CTPP) (Ishida et al., 2006; Migita et al., 2007; Hamajima et al., 2008).

\section{Urine sampling}

In order to assess intakes of salt, fruit and vegetables, second morning voiding urine (SMVU) was sampled at the hospital. We estimated 24-hour urinary sodium and potassium excretions using SMVU according to Kawasaki's formula (Kawasaki et al., 1993).

\section{Statistical analysis}

Age-adjustment with the World Population (IARC, 2003) was made for values of stomach cancer incidence rates, $H$. pylori-related markers, smoking rates, and urinary excretions of salt and potassium. The relations between positive UBT and positive HAV-Ab were evaluated by Chi-square test. The associations across the SNPs (IL-1 $\beta$ C-31T, TNF- $\alpha$ T-1031C, and PTPN11 G/A at intron 3 ) and positive UBT were examined by Chisquare test after confirming that the frequencies of the control groups were within Hardy-Weinberg equilibrium. All data were analyzed by SAS software (ver. 8.0, SAS Institute) and Excel.

\section{Approval from ethics committee}

The protocol was approved by the Ethics Committee of the Nagoya City University Graduate School of Medical
Sciences, and the Research and Development Unit/ Research Ethics Committee of the Medical Faculty of the University of Udayana/Sanglah Hospital, Denpasar, Bali in Indonesia.

\section{Informed consent}

All subjects voluntarily took part in this study. Written informed consent was obtained from all participants and from the parents of minors.

\section{Results}

Age-adjusted annual incidence rates of stomach cancer in Bali were estimated to be $0.6 / 105$ for men and $0.5 / 105$ for women, approximately 1/100th of those in Japan (RGPCRJ, 2003), and were also lower than those of Malay people in Malaysia (Ministry of Health, Malaysia, 2002) and Singapore (IARC, 2002) (Table 1).

As shown in Table 2, mean ages \pm SD were $37.7 \pm 15.4$ years old for men and $38.4 \pm 15.4$ for women. The major ethnic group was Balinese (92\%) (data not shown), most of whom were Hindus (92\%). Age-adjusted positive rates of UBT in Bali were 9\% (95\% confidence interval: $2-15)$ for men and $7 \%$ (1-12) for women. Positive rates of pepsinogen test were $0 \%(0-0)$ for men and $1 \%(0-4)$ for women in Bali, both of which were significantly lower than the Japanese values ( $\mathrm{p}<0.01$ ) (Watase et al., 2004).

In Bali, salt excretions were estimated to be $13.3 \pm 4.1$ $\mathrm{g} /$ day for men and 11.1 $\pm 3.1 \mathrm{~g} /$ day for women, and there was no significant difference between the excretions of the Balinese participants and the consumption in Japan (Ministry of Health, Labour and Welfare, Japan, 2008). In addition, we found no significant difference in the intake of salt and salty foods between $H$. pylori-positive and -negative Balinese subjects (data not shown). Potassium excretion figures were $3.2 \pm 0.7 \mathrm{~g} /$ day for men and $2.8 \pm 0.6$ $\mathrm{g} /$ day for women in Bali, being significantly higher than those in Japan $(\mathrm{p}<0.05)$ (Ministry of Health, Labour and Welfare, Japan, 2008).

Age-adjusted smoking rates of those 20 years of age or over were significantly lower for both men and women in Bali than those in Japan $(\mathrm{p}<0.05)$ (Ministry of Health,

Table 1. Age-adjusted Annual Incidence Rates of Stomach Cancer (per 100,000)

\begin{tabular}{lcc}
\hline & Men & Women \\
\hline Bali J & 0.6 & 0.5 \\
Japan IJ & 67 & 27 \\
Peninsular Malaysia IJI & 7.6 & 5.1 \\
$\quad$ Malay & 3.4 & 2.1 \\
$\quad$ Chinese & 13.5 & 9.1 \\
$\quad$ Indian & 8.2 & 7.4 \\
Singapore IJ & & \\
$\quad$ Malay & 6.6 & 4.0 \\
$\quad$ Chinese & 25.6 & 12.4 \\
$\quad$ Indian & 9.0 & 6.0 \\
\hline
\end{tabular}

I: Age-adjusted annual incidence rates during 2001-2005 calculated using the data from Bali Cancer Registration, $\mathbf{I J}$ : Values were those of 1998 cited from the reference (RGPCRJ, 2003), IJg: Values were cited

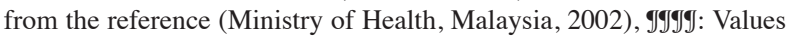
were cited from the reference (IARC, 2002) 
Rare Helicobacter pylori Infection May Explain Low Stomach Cancer Incidence: Ecological Observations in Bali, Indonesia

Table 2. Demographic Characteristics, H. pylori-related Markers, Urinary Excretion of Salt and Potassium, and Smoking and Alcohiol Consumption Rates in Bali vs. Japan

\begin{tabular}{|c|c|c|c|c|}
\hline & \multicolumn{2}{|c|}{ Bali, Indonesia } & \multicolumn{2}{|c|}{ Japan } \\
\hline & $\begin{array}{c}\text { Men } \\
\mathrm{n}=136\end{array}$ & $\begin{array}{l}\text { Women } \\
\mathrm{n}=155\end{array}$ & Men & Women \\
\hline Mean age \pm SD & $37.7 \pm 15.4$ & $38.4 \pm 15.4$ & & \\
\hline BMI ( $95 \%$ confidence interval) & $\begin{array}{c}21.4(20.6-22.2) \\
n=129\end{array}$ & $\begin{array}{c}21.7(21.1-22.4) \\
\mathrm{n}=151\end{array}$ & & \\
\hline Positive UBT (\%) & $\begin{array}{c}9.0(2.0-15.0) \\
\mathrm{n}=134\end{array}$ & $\begin{array}{c}7.0(1.0-12.0) \\
\mathrm{n}=153\end{array}$ & NA & NA \\
\hline Positive UBT $=>30 \mathrm{yr}(\%)$ & $\begin{array}{c}7.3(1.9-12.7) \\
\mathrm{n}=94\end{array}$ & $\begin{array}{c}6.5(2.0-11.1) \\
\mathrm{n}=112\end{array}$ & NA & NA \\
\hline Positive pepsinogen test (\%) & $\begin{array}{c}0(0.0-0.0)^{*} \\
\mathrm{n}=133\end{array}$ & $\begin{array}{c}1.0(0.0-4.0)^{*} \\
\mathrm{n}=153\end{array}$ & $23.0(22.0-25.0) \#$ & $22.0(20.0-23.0) \#$ \\
\hline Estimated excretion of salt (mean $\pm \mathrm{SD})(\mathrm{g} /$ day) & $\begin{array}{c}13.3 \pm 4.1 \\
\mathrm{n}=136\end{array}$ & $\begin{array}{c}11.1 \pm 3.1 \\
\mathrm{n}=155\end{array}$ & $\begin{array}{c}11.8 \pm 5.1 \# \# \\
\mathrm{n}=4163\end{array}$ & $\begin{array}{c}10.3 \pm 4.4 \# \# \\
\mathrm{n}=4732\end{array}$ \\
\hline Estimated excretion of potassium $($ mean $\pm S D)(g /$ day $)$ & $\begin{array}{c}3.2 \pm 0.7^{*} \\
\mathrm{n}=136\end{array}$ & $\begin{array}{c}2.8 \pm 0.6^{*} \\
\mathrm{n}=155\end{array}$ & $\begin{array}{c}2.5 \pm 1.0 \# \# \\
\mathrm{n}=4163\end{array}$ & $\begin{array}{c}2.3 \pm 1.0 \# \# \\
\mathrm{n}=4732\end{array}$ \\
\hline Smoking rate $=>20 \mathrm{yr}(\%)$ & $\begin{array}{c}18.8(9.5-28.1)^{*} \\
\mathrm{n}=105\end{array}$ & $\begin{array}{c}1.1(0.0-2.6)^{*} \\
\mathrm{n}=127\end{array}$ & $45.3(44.8-45.8) \dagger$ & $13.4(13.1-13.7) \dagger$ \\
\hline Alcohol consumption => $20 \mathrm{yr}(\%)$ & $\begin{array}{c}15.2(5.8-24.6)^{*} \\
\mathrm{n}=104\end{array}$ & $\begin{array}{c}1.1(0.0-2.7)^{*} \\
\mathrm{n}=124\end{array}$ & $\begin{array}{c}36.7\left(\begin{array}{c}(36.3-37.2) \# \# \\
\mathrm{n}=3450\end{array}\right.\end{array}$ & $\begin{array}{c}9.3(9.0-9.5) \# \# \\
n=4047\end{array}$ \\
\hline Recent use of antibiotics (\%) & $\begin{array}{c}17(8-26) \\
\mathrm{n}=129\end{array}$ & $\begin{array}{c}13(5-22) \\
n=151\end{array}$ & & \\
\hline Drinking well water (\%) & $\begin{array}{c}18(9-26) \\
n=129\end{array}$ & $\begin{array}{c}21(12-31) \\
\mathrm{n}=151\end{array}$ & & \\
\hline
\end{tabular}

*: Significantly different from Japan $(\mathrm{p}<0.01), \uparrow$ : Calculated using the 2006 data from the reference (Ministry of Health, Labor and Welfare, Japan, 2006) and age-adjusted by the World Population, NA: not available, \#: Data from the reference (Watase et al., 2004), \#\#: 2005 data from the reference (Ministry of Health, Labor and Nutrition, Japan, 2008), All data in Bali were age-adjusted with the World Population

Table 3. H. pylori IgG Seroprevalence According to Survey AreaJ

\begin{tabular}{|c|c|c|c|}
\hline & \multicolumn{3}{|c|}{ Serum H. pylori $\operatorname{IgG}(+)(\%)$} \\
\hline & Total & Men & Women \\
\hline Bali, Indonesia & $\begin{array}{c}2.0(0.0-4.0) \\
n=286\end{array}$ & $\begin{array}{c}1.0(0.0-3.0) \\
\mathrm{n}=133\end{array}$ & $\begin{array}{c}3.0(0.0-5.0) \\
n=153\end{array}$ \\
\hline$>=30 \mathrm{yr}$ & $\begin{array}{c}3.6(1.0-6.0) \\
n=206\end{array}$ & $\begin{array}{c}3.5(0.0-8.0) \\
\mathrm{n}=94\end{array}$ & $\begin{array}{c}3.7(0.0-7.0) \\
\mathrm{n}=112\end{array}$ \\
\hline Yogyakarta, Indonesia* & $\begin{array}{c}4.6(0.0-11.3) \\
n=91\end{array}$ & $\begin{array}{c}5.0(0.0-13.0) \\
n=52\end{array}$ & $\begin{array}{c}4.0(0.0-9.0) \\
\mathrm{n}=39\end{array}$ \\
\hline Japan $* *$ & & $62.0(58.0-65.0)$ & $57.0(53.0-60.0)$ \\
\hline Kuala Lumpur, Malaysia*** & 26.5 & 27.2 & 22.2 \\
\hline Malay & 11.9 & & \\
\hline Chinese & 26.7 & & \\
\hline Indian & 49.4 & & \\
\hline Kota Kinabalu, Malaysia*** & 55.0 & 56.6 & 43.5 \\
\hline Malay & 29.2 & & \\
\hline Chinese & 49.3 & & \\
\hline Indigenous native people & 65.3 & & \\
\hline \multicolumn{4}{|l|}{ Singapore $* * * *$} \\
\hline Malay & & 30.1 & 26.1 \\
\hline Chinese & & 46.8 & 45.8 \\
\hline Indian & & 51.1 & 45.1 \\
\hline
\end{tabular}

*: Data from the reference (Tokudome et al., 2005a); **: Data from the reference (Kikuchi et al., 2000); ***: Data from the reference (Goh and Parasakthi, 2001); ****: Data from the reference (Ang et al., 2005); IAll data in Indonesia were age-adjusted with the World Population

Labour and Welfare, Japan, 2006). Alcohol consumption rates of those 20 years of age or over in the Balinese were $15.2 \%(5.8-24.6)$ for men and $1.1 \%(0.0-2.7)$ for women, which were also significantly lower than those in Japan (Ministry of Health, Labour and Welfare, Japan, 2008). Percentages of recent use of antibiotics were $17 \%$ for men and $13 \%$ for women. Rates of using well water were $18 \%$ for men and $21 \%$ for women.

Positive H. pylori IgG antibodies were only $1 \%(0-3)$ for men and $3 \%(0-5)$ for women in Bali, which were significantly lower than the $62 \%(58-65)$ and $57 \%$ (53$60)$ for men and women, respectively, in Japan $(\mathrm{p}<0.05)$ (Kikuchi et al., 2000) (Table 3). The values in Bali were lower than those of Malay people in Malaysia (Goh and 
Table 4. CagA IgG Antibodies in H. pylori IgG-positive Subjects

\begin{tabular}{lccc}
\hline & $\mathrm{CagA}(+) / \mathrm{HP}(+)$ & $\mathrm{CagA}(-) / \mathrm{HP}(+)$ & Total \\
\hline Bali & 5 & 2 & 7 \\
$(\%)$ & $71.4 \%$ & $28.6 \%$ & $100 \%$ \\
Japan* & 281 & 102 & 383 \\
$(\%)$ & $73.4 \%$ & $26.6 \%$ & $100 \%$ \\
\hline
\end{tabular}

*: Measured in Japanese gastric cancer cases from the reference (Sasazuki et al., 2006); No significant difference according to Chisquare test

Table 5. Seroprevalence of Anti-HAV IgG According to Survey Area

\begin{tabular}{lccc}
\hline & \multicolumn{3}{c}{ Serum HAV IgG $(+)(\%)$} \\
\hline Bali, Indonesia & 76.3 & Men & Women \\
& $\mathrm{n}=288$ & $\mathrm{n}=133$ & $\mathrm{n}=155$ \\
$>40 \mathrm{yr}$ & 96.0 & 98.6 & 93.4 \\
& $\mathrm{n}=195$ & $\mathrm{n}=88$ & $\mathrm{n}=107$ \\
Japan* & 12.2 & 12.7 & 11.7 \\
Malaysia** & 67.0 & 68.4 & 65.3 \\
$>$ 40 yr & 96.0 & & \\
Malay & 70.3 & & \\
Chinese & 55.9 & & \\
$\quad$ Indian & 80.6 & & \\
\hline
\end{tabular}

*: Data from the reference (Kiyohara et al., 2007); **: Data from the reference (Tan et al., 1986)

Table 6. Associations Across Genetic Polymorphisms and UBT Positivity

\begin{tabular}{lccc}
\hline & UBT(+) & UBT(-) & Odds ratio (95\% CI) \\
\hline IL1-beta C-31T & 5 & 37 & \\
TT & 16 & 231 & \\
TC+CC & & & $1.95(0.67-5.64)$ \\
TNF-A T-1031C & 11 & 122 & \\
TT & 10 & 146 & \\
TC+CC & & & $1.32(0.54-3.20)$ \\
PTPN11 G/A at intron 3 & & \\
GG & 13 & 163 & \\
GA+AA & 8 & 105 & $1.05(0.42-2.61)$ \\
& & & \\
\hline
\end{tabular}

The genetic polymorphisms in the control groups were within HardyWeinberg equilibrium

Parasakthi, 2001) and Singapore (Ang et al., 2005).

There was no significant difference between the percentages of positive CagA IgG among positive $H$. pylori IgG subjects of $71.4 \%$ (5/7) in Bali vs. $73.4 \%$ (281/383) in Japan (Sasazuki et al., 2006) (Table 4).

Positive rates of HAV-Ab were $78.9 \%$ in men and $74.2 \%$ in women in Bali, which were almost as high as those in Malaysia (Tan et al., 1986) (Table 5), but higher than the corresponding figures in Japan (Kiyohara et al., 2007). Positive rates of HAV-Ab of those over 40 years of age were $98.6 \%$ for men and $93.4 \%$ for women. There were no significant relations between positive UBT and positive HAV antibodies in the Balinese, being compatible with the observations in Japan (Furuta et al., 1997).

The genetic polymorphisms in the control groups were within Hardy-Weinberg Equilibrium. No significant associations were noted across IL- $1 \beta \mathrm{C}-31 \mathrm{~T}, \mathrm{TNF}-\alpha$ T-1031C, or PTPN11 G/A at intron 3 and UBT positivity (Table 6).

\section{Discussion}

We noted a very rare prevalence of $H$. pylori along with chronic atrophic gastritis and low incidence of stomach cancer in Bali, a result similar to those of our prior studies in other areas of Indonesia (Tokudome et al., 2005a; 2005b). However, there were low smoking rates together with high intakes of fruit and vegetables, and no difference in the consumption of salt and salty foods between Bali and Japan. Thus, the low incidence of stomach cancer in Bali appeared attributable to a rare $H$.pylori infection and chronic atrophic gastritis along with low smoking rates and high consumption of fruit and vegetables.

We used UBT to detect the current $H$.pylori infection. UBT is regarded as the gold standard, which may be more sensitive than serological examinations, including H. pylori IgG (Cohen et al., 1999). Actually, although all our subjects with positive $H$. pylori $\operatorname{IgG}$ showed positive UBT, those with positive UBT were not always positive for H. pylori $\mathrm{IgG}$. In other words, the specificity of the UBT test was distorted by bacteria having a urease function other than H.pylori. Nevertheless, we confirmed the low prevalence of $H$. pylori in Bali not only by UBT but also by $H$. pylori $\operatorname{IgG}$ antibodies.

H. pylori was also identified as a causative factor for chronic atrophic gastritis, a precursor lesion of stomach cancer, as was diagnosed using a PG test in a non-invasive examination (Oishi et al., 2006). The low positive rate of PG tests conducted in Bali was consistent with the fact that a history of gastric lesions rarely encountered by local clinicians (Moestikanigsih, personal communication), which may be due to the low positive rate of $H$. pylori. These results also appeared to be compatible with the low incidence of stomach cancer in Bali.

The cagA gene of $H$. pylori has been suspected of being a virulent factor for atrophic gastritis and stomach cancer (Parsonnet et al., 1997). We found that positive rates of $\mathrm{CagA}$ IgG detected in those with positive $H$. pylori $\mathrm{IgG}$ in Bali were as frequent as those in Japan. However, since the numbers of positive CagA IgG subjects in Bali appeared insufficient to establish the virulence of the cag A gene, we were unable to detect any statistically significant associations between that gene and stomach cancer.

The intake of salt and salty foods has been regarded as one of the risk factors for stomach cancer (WCRF/ AICR, 2007; Tsugane et al., 2004). It is conceivable that high intakes of salt and salty foods along with $H$. pylori infection synergistically affect the development of stomach cancer. However, the high consumption of salt and salty foods observed in both Bali and Japan does not in itself seem sufficiently responsible to explain the difference in the stomach cancer incidence between both areas.

We observed that the estimated excretion of potassium in Bali as a marker of the consumption of fruit and vegetables was significantly higher than the intake in Japan (Ministry of Health, Labour and Welfare, Japan, 
Rare Helicobacter pylori Infection May Explain Low Stomach Cancer Incidence: Ecological Observations in Bali, Indonesia

2008). Case-control studies have suggested that such consumption reduces gastric carcinogenesis (Kato et al., 1990; Inoue et al., 1994; Nishimoto et al., 2002; Goh et al., 2007). On the other hand, smoking has been well-known as a risk factor for stomach cancer (IARC, 2003). From our results, the low incidence of stomach cancer may be in part attributable to the higher consumption of fruit and vegetables and lower smoking rates in the Balinese.

It is suggested that $H$. pylori infection spreads via a fecal-oral, gastro-oral or oral-oral route (Graham and Graham, 2002), in contrast with HAV infection which is used as a marker of fecal-oral infection (Furuta et al., 1997). HAV may be transmitted by HAV contaminated foods and water (Serres et al., 1999). In agreement with a previous study (Furuta et al., 1997), the seropositivity of HAV did not synchronize with the seroprevalence of $H$. pylori in Bali. These results were compatible with the observations in Malay people in Malaysia (Goh and Parasakthi, 2001; Tan et al., 1986) (Table 5). One reason we were unable to verify the difference in infection routes/ modes between the two microorganisms may be that HAV is contracted directly by a single infection, whereas $H$. pylori infections appear to be established by multiple transmissions.

The inflammatory cytokine genes including IL-1 $\beta$ C-31T, TNF- $\alpha$ T-1031C, and PTPN11 G/A at intron 3 have been suggested to be associated with developing atrophic gastritis and gastric cancer (El-Omar et al., 2000; Goto et al., 2006; Sugimoto et al., 2007; Santos et al., 2012; Tahara et al., 2012; Zhao et al., 2013). However, the present study could not detect the association across these genetic polymorphisms and UBT positivity partly due to the small number of study subjects. Further investigation is warranted to identify an individual having a high risk of gastric cancer.

In terms of study limitations, an ecological study is admittedly generally recognized to be a rather unreliable method of generating evidence because it is not completely possible to eliminate ecological fallacies. The cancer incidence data were derived from a hospital-based cancer registry, not a population-based registration. Moreover, subjects were not all randomly recruited from the people of Bali, and the sample size in this study may be rather small to be representative with respect to the risk factors being studied. However, the very low prevalence of $H$. pylori observed in this study did not seem to be due to ecological errors or the small sample size.

In conclusion, we have confirmed that the exceptionally low prevalence of $H$. pylori infections may bring about not only a rare prevalence of chronic atrophic gastritis but also a low incidence of stomach cancer. Thus, H. pylori infection appeared to be a critical factor that determines gastric carcinogenesis, indicating that the prevention and control of stomach cancer may be successfully achieved by infection control and the eradication of $H$. pylori.

\section{Acknowledgements}

This study was supported in part by a Grant-in-Aid for Scientific Research on Priority Areas from the Ministry of Education, Culture, Sports, Science and Technology,
Japan. We wish to thank Ms Miyako Kimura, Ms Keiko Higuchi, Ms Sakae Koshiba, Ms Nobuko Sato, and Ms Miwa Mori for their special and valuable assistance and encouragement.

\section{References}

Ang TL, Fock KM, Dhamodaran S, et al (2005). Racial differences in Helicobacter pylori, serum pepsinogen and gastric cancer incidence in an urban Asian population. $J$ Gastroenterol Hepatol, 20, 1603-9.

Cohen H, Rose S, Lewin DN, et al (1999). Accuracy of four commercially available serologic tests, including two officebased tests and a commercially available 13C urea breath test, for diagnosis of Helicobacter pylori. Helicobacter, $\mathbf{4}$, 49-53.

Fiore AE (2004). Hepatitis A transmitted by food. Clin Infect Dis, 38, 705-15.

Furuta T, Kamata T, Takashima M, et al (1997). Study of transmission routes of Helicobacter pylori in relation to seroprevalence of hepatitis A virus. J Clin Microbiol, 35 , 1891-3.

Goh KL, Parasakthi N (2001). The racial cohort phenomenon: seroepidemiology of Helicobacter pylori infection in a multiracial South-East Asian country. Eur J Gastroenterol Hepatol, 13, 177-83.

Goh KL, Cheah PL, Noorfaridah MD, et al (2007). Ethnicity and $H$. pylori as risk factors for gastric cancer in Malaysia: a prospective case control study. Am J Gastroenterol, 102, 40-5.

Goto Y, Ando T, Yamamoto K, et al (2006). Association between serum pepsinogens and polymorphism of PTPN11 encoding SHP-2 among Helicobacter pylori seropositive Japanese. Int J Cancer, 118, 203-8.

Graham DY, Klein PD, Evans DJ Jr, et al (1987). Campylobacter pylori detected noninvasively by the $13 \mathrm{C}$-urea breath test. Lancet, 1, 1174-7.

Graham KS, Graham DY (2002). H. pylori-associated Gastrointestinal Disease, 2nd ed, Handbooks in Health Care, Newton, PA.

Hamajima N, Rahimov B, Malikov Y, et al (2008). Associations between a PTPN11 polymorphism and gastric atrophyopposite in Uzbekistan to that in Japan. Asian Pac J Cancer Prev, 9, 217-20.

International Agency for Research on Cancer (IARC) (1994). Schistosomes, liver flukes, and Helicobacter pylori. IARC monographs programme on the evaluation of carcinogenic risks to humans, Vol. 61, IARC, Lyon.

IARC (2002). Cancer incidence in five continents, Vol.8, IARC, Lyon.

IARC (2003). World cancer report, IARC, Lyon.

Inoue M, Tajima K, Hirose K, et al (1994). Life-style and subsite of gastric cancer - joint effect of smoking and drinking habits. Int J Cancer, 56, 494-9.

Ishida Y, Goto Y, Kondo T, et al (2006). Eradication rate of Helicobacter pylori according to genotypes of CYP2C19, IL-1B, and TNF-A. Int J Med Sci, 3, 135-40.

Kato I, Tominaga S, Ito Y, et al (1990). A comparative casecontrol analysis of stomach cancer and atrophic gastritis. Cancer Res, 50, 6559-64.

Kawasaki T, Itoh K, Uezono K, et al (1993). Estimation of 24hour urinary sodium and potassium excretion from predicted value of 24-hour urinary creatinine excretion and fractional urine sodium/creatinine and potassium/creatinine ratio. Seventh Symposium Salt, 2, 257-62.

Kikuchi S, Nakajima T, Kobayashi O, et al (2000). Effect of age on the relationship between gastric cancer and H.pylori.Jpn 
J Cancer Res, 91, 774-9.

Kiyohara T, Sato T, Totsuka A, et al (2007). Shifting seroepidemiology of hepatitis A in Japan, 1973-2003. Microbiol Immunol, 51, 185-91.

Migita K, Maeda Y, Abiru S, et al (2007). Polymorphisms of interleukin-1beta in Japanese patients with hepatitis B virus infection. J Hepatol, 46, 381-6.

Miki K, Morita M, Sasajima M, et al (2003). Usefulness of gastric cancer screening using the serum pepsinogen test method. Am J Gastroenterol, 98, 735-9.

Ministry of Health, Labour and Welfare, Japan [website on the internet]. The National Health and Nutrition Survey in Japan, 2006 (in Japanese).

Ministry of Health, Labour and Welfare, Japan (2008). The National Health and Nutrition Survey in Japan, 2005 (in Japanese), Daiichi Shuppan, Tokyo.

Ministry of Health, Malaysia. [website on the internet]. The First Report of the National Cancer Registry Cancer Incidence in Malaysia 2002.

Nishimoto IN, Hamada GS, Kowalski LP, et al (2002). Risk factors for stomach cancer in Brazil (1): a case-control study among non-Japanese Brazilians in Sao Paulo. Jpn J Clin Oncol, 32, 277-83.

Ohata H, Kitauchi S, Yoshimura N, et al (2004). Progression of chronic atrophic gastritis associated with $H$. pylori infection increases risk of gastric cancer. Int J Cancer, 109, 138-43.

Oishi Y, Kiyohara Y, Kubo M, et al (2006). The serum pepsinogen test as a predictor of gastric cancer: the Hisayama Study. Am J Epidemiol, 163, 629-37.

El-omar EM, Cariington M, Chow WH, et al (2000). Interleukin-1 polymorphisms associated with increased risk of gastric cancer. Nature, 404, 398-402.

Parsonnet J, Friedman GD, Vandersteen DP, et al (1991). $H$. pylori infection and the risk of gastric carcinoma. $N$ Engl $J$ Med, 325, 1127-31.

Parsonnet J, Friedman GD, Orentreich N, et al (1997). Risk for gastric cancer in people with CagA positive or CagA negative H. pylori infection. Gut, 40, 297-301.

Research Group for Population-based Cancer Registration in Japan (RGPCRJ) (2003). Cancer incidence and incidence rates in Japan in 1998: Estimates Based on Data from 12 Population-based Cancer Registries. Jpn J Clin Oncol, 33, 241-5.

Santos JC, Ladeira MS, Pedrazzoli J Jr, et al (2012). Relationship of IL-1 and TNF- $\alpha$ polymorphisms with Helicobacter pylori in gastric diseases in a Brazilian population. Braz J Med Biol Res, 45, 811-7.

Sasazuki S, Inoue M, Iwasaki M, et al (2006). Effect of Helicobacter pylori infection combined with CagA and pepsinogen status on gastric cancer development among Japanese men and women: a nested case-control study. Cancer Epidemiol Biomarkers Prev, 15, 1341-7.

Serres GD, Cromeans TL, Levesque B, et al (1999). Molecular confirmation of hepatitis A virus from well water: epidemiology and public health implications. JID, 179, 3743.

Soeripto, Indrawati, Indrayanti (2003). Gastro-intestinal cancer in Indonesia. Asian Pac J Cancer Prev, 4, 289-96.

Sugimoto M, Furuta T, Shirai N, et al (2007). Different effects of polymorphisms of tumor necrosis factor-alpha and interleukin- 1 beta on development of peptic ulcer and gastric cancer. J Gastroenterol Hepatol, 22, 51-9.

Tahara T, Shibata T, Yamashita H, et al (2012). Synergistic effect of IL-1 $\beta$ and TNF- $\alpha$ polymorphisms on the $H$.pylori-related gastric pre-malignant condition. Hepatogastroenterol, $\mathbf{5 9}$, 2416-20.

Tan DS, Fang R, Collett D, et al (1986). A seroepidemiologic study of hepatitis A in Malaysia. Southeast Asian J Trop Med Public Health, 17, 201-4.

Tokudome S, Soeripto, Triningsih FXE, et al (2005a). Rare Helicobacter pylori infection as a factor for the very low stomach cancer incidence in Yogyakarta, Indonesia. Cancer Letters, 219, 57-61.

Tokudome S, Samsuria WD, Soeripto, et al (2005b). Helicobacter pylori infection appears essential for stomach carcinogenesis: observations in Semarang, Indonesia. Cancer Sci, 96, 873-5.

Tsugane S, Sasazuki S, Kobayashi M, et al (2004). Salt and salted food intake and subsequent risk of gastric cancer among middle-aged Japanese men and women. Br J Cancer, 90, 128-34.

Watase H, Inagaki T, Yoshikawa I, et al (2004). Five years' follow-up study of gastric cancer screening using the serum pepsinogen test method in Adachi City, Japan. Jpn Assoc Cancer Detect Diag, 11, 77-81.

World Cancer Research Fund in association with American Institute for Cancer Research (WCRF/AICR) (2007). Food, nutrition, physical activity, and the prevention of cancer: a global perspective, AICR, Washington, D.C.

Zhao Y, Wang JW, Tanaka T, et al (2013). Association between TNF- $\alpha$ and IL-1 $\beta$ genotypes vs Helicobacter pylori infection in Indonesia. World J Gastroenterol, 19, 8758-63. 